\title{
Banana pseudostem substitution in wheat flour biscuits enriches the nutritional and antioxidative properties with considerable acceptability
}

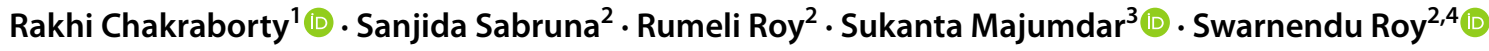

Received: 18 September 2020 / Accepted: 19 December 2020 / Published online: 11 January 2021

(c) The Author(s) 2021 OPEN

\begin{abstract}
Biscuits prepared from composite flours substituted with unconventional plant resources have been considered important for enriching the overall nutritional quality. The present study was undertaken to explore the potential of banana pseudostem flour for the valorization of wheat flour biscuits. At the same time, the study attempts to address the problem of bioresource wastage as huge amounts of banana pseudostem are wasted every year after harvesting of the fruits. In this study, composite flours were prepared by partially substituting wheat flour with banana pseudostem core flour (BPF10, BPF20, BPF30) in different proportions $(10,20,30 \% \mathrm{w} / \mathrm{w})$, and biscuits were prepared from these composite flour formulations. Analyses of the physicochemical properties, pasting properties, colour and texture, quantification of phytochemicals and antioxidant properties, and overall sensory evaluation of the flours and biscuits were performed for comparative evaluation. BPF-substituted composite flours showed higher moisture and ash content, pasting temperature and water and oil absorption capacity. BPF-fortified biscuits were found to be rich in ash content, protein, proline, antioxidative phytochemicals, viz. phenols, flavonoids, tannins, ascorbate, and alkaloids, whereas fat, moisture content, and viscosity were comparatively lower than that of the control (wheat flour biscuits). Significant free radical scavenging activities of the BPF-substituted biscuits were also observed. Colour and texture analysis showed desirable changes in lightness $\left(L^{*}\right)$, yellowness $\left(b^{*}\right)$, chroma $\left(C^{*}\right)$, fracturability, and hardness of the BPF-substituted biscuits. Most importantly, considering the sensory characteristics like taste and crispiness, control and BPF10 biscuits were highly comparable. Therefore, the formulation of BPF-substituted biscuits presents an effective way to utilize banana pseudostems, which is also rich in nutraceutical and antioxidative properties.
\end{abstract}

Keywords Antioxidant $\cdot$ Banana pseudostem $\cdot$ Biscuits $\cdot$ Composite flour $\cdot$ Musa balbisiana $\cdot$ Sensory evaluation

\section{Introduction}

Banana (Musa spp.) is widely cultivated for its fruits, and almost all the cultivated species are derived from hybridization of two wild diploid species-Musa acuminata and Musa balbisiana [1]. Banana fruits are rich in carbohydrates, vitamins, minerals, and several essential amino acids. The fruits are highly valued for fresh consumption as well as for their utilizations in numerous food products like puree, flour, chips, jam, vinegar, wine, juice, etc. [2]. Apart from the fruits, the inflorescence, pseudostem, rhizome and leaves of banana are also consumed locally and

$\triangle$ Swarnendu Roy, swarnendubotany@nbu.ac.in | ${ }^{1}$ Department of Botany, Acharya Prafulla Chandra Roy Government College, Himachal Vihar, Matigara, Siliguri, West Bengal 734010, India. ${ }^{2}$ Molecular and Analytical Biochemistry Laboratory, Department of Botany, University of Gour Banga, Malda, West Bengal 732103, India. ${ }^{3}$ Microbiology and Microbial Biotechnology Laboratory, Department of Botany, University of Gour Banga, Malda, West Bengal 732103, India. ${ }^{4}$ Present Address: Plant Biochemistry Laboratory, Department of Botany, University of North Bengal, Raja Rammohunpur, Siliguri, West Bengal 734013, India. 
traditionally in several regions [3]. India is the largest producer of banana in the world with about 31 million tonnes of fruits produced per year [4]. Nearly 1 million hectares of land is under banana cultivation, which is in addition to the plants growing in wild condition [4]. A huge amount of agricultural waste is thus generated every year after the harvesting of fruits in the form of pseudostems and leaves. Therefore, the viable utilization of these agro residues is of utmost importance to reduce wastage.

The banana pseudostem is particularly rich in cellulose, hemicellulose, protein, fat and dietary fibres along with other nutritive elements [5]. The presence of polyphenols and flavonoids, viz. ferulic acid, cinnamic acid, catechin, gingerol, with promising antioxidative activities has been reported [6]. It was shown that the methanolic extract of the pseudostem possesses significant hypolipidemic and antihypercholesterolemic properties [7]. Banana pseudostems also exhibited antimicrobial properties against both gram-positive and gram-negative bacteria and even antitumor activity against hepatocellular carcinoma (HepG-2) and human colon carcinoma (HCT-116) cell lines [8]. Therefore, consumption of banana pseudostem can be beneficial, and hence, materializing its usage in food products appears noteworthy. In this connection, some attempts have been undertaken in the past. Sharma et al. [9] reported the preparation of a functional juice from pseudostem with prebiotic properties containing glucooligosaccharides and D-allulose. Carboxymethylcellulose obtained from banana pseudostem was reported to be used as a natural thickening and gelling agent in food items [10]. Apart from that, the fermentation of banana pseudostem for bioethanol production was also reported [11].

One of the most popular ways of exploiting the underutilized plant resources has been through the preparation of composite flours. Composite flours are mixtures of several flours obtained from cereals, legumes or other plant resources with or without the presence of wheat flours. Composite flours have gained much importance owing to its enriched nutritional profile and better digestibility [12]. Moreover, the usage of composite flours can help overcome the production deficit of wheat in several tropical countries [13]. It could also enhance the scope for utilizing unconventional domestic agricultural resources in flour making, limiting unnecessary wastage at the same time. Preparation of baked products from composite flours has received special attention for the supplementation of good quality proteins, essential amino acids, vitamins, minerals and dietary fibres [14]. In this connection, flours made from banana fruits and peels (ripe and unripe) have been successfully converted into several baked products, viz. slowly digestible cookies, high-fibre bread, snacks, noodles, pasta and cakes
[15]. Agama-Acevedo et al. [16] reported the usage of unripened banana flour in cookies that remarkably enhanced the contents of fibre and resistant starch, which in turn reduced starch digestibility and glycemic index. Improved textural and rheological properties were also observed in dough and bread substituted with whole green banana flour [17]. However, to date, very few attempts have been made to transform the pseudostem into edible baked forms. Therefore, the utilization of banana pseudostem into baked products demands special attention. Among the baked products, biscuit or cookie preparations are quite popular due to their ready-to-eat form, palatability, aroma, texture quality and relatively longer shelf life [18].

In the present study, we have attempted to utilize the flour derived from the pseudostem core of $M$. balbisiana Colla (Family-Musaceae), which generally grows in wild conditions. The plant has been less valued for its fruits, and the pseudostem core is often consumed as a vegetable by the local people. However, the consumption of pseudostem is not so popular, and thus, the feasibility of biscuit preparation from banana pseudostem core flour was explored in the present study. In this connection, the preparation of biscuits from the composite flours obtained by mixing wheat and banana pseudostem core flours in different proportions was done and then evaluated in terms of physicochemical, functional, antioxidant and sensory characteristics. The abundance of high protein and lesser fat content, antioxidative phytochemicals and free radical scavenging properties enriched the overall quality of the partially substituted wheat flour biscuits. Also, the colour and textural attributes with considerable acceptance from the volunteers in terms of sensory parameters indicated the feasibility of using banana pseudostem core flour in biscuits.

\section{Materials and methods}

\subsection{Plant material}

Fresh pseudostem core of $M$. balbisiana Colla were obtained from the vegetable market (Malda, West Bengal, India) (Fig. 1). The outer sheath of the banana pseudostem was peeled off to obtain the inner central core (diameter $<6 \mathrm{~cm}$ ), which was then cut into small pieces, and dried in a hot air oven at $50^{\circ} \mathrm{C}$ for $48 \mathrm{~h}$ (Fig. 1). After drying, the plant sample was milled using a mechanical grinder and sieved through $0.2-\mathrm{mm}$ sieve to obtain a fine powder (Fig. 1). The powder was finally stored in an airtight container at $4{ }^{\circ} \mathrm{C}$ for further use. 

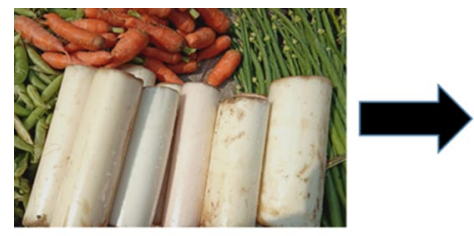

a

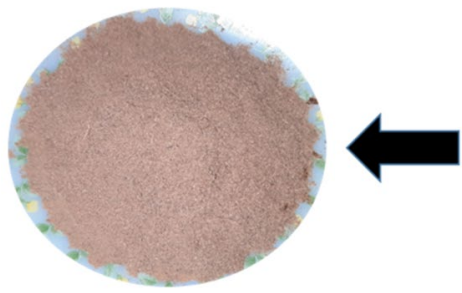

$\mathrm{d}$

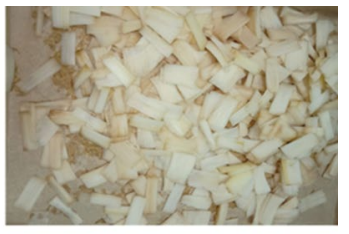

b

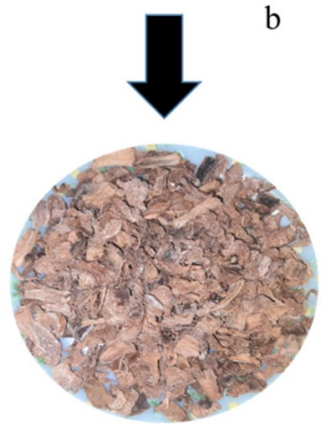

c
Fig. 1 a Banana pseudostems procured from the local market, b Pseudostems chopped into small pieces for drying, c Dried pseudostem for milling, d Pseudostem flour (BPF) sample

\subsection{Preparation of composite flour}

Refined wheat flour (Aashirvaad, ITC Kolkata, India) containing about $11.8 \mathrm{~g}$ protein and $1.7 \mathrm{~g}$ fat per $100 \mathrm{~g}$ was purchased from a local retail outlet (Malda, West Bengal, India). Banana pseudostem flour (BPF) was mixed to partially substitute the wheat flours by 10,20 and $30 \%(\mathrm{w} / \mathrm{w})$. The formulated composite flour samples were again stored in airtight containers and labelled as BPF10, BPF20 and BPF30, respectively.

\subsection{Preparation of biscuits}

Biscuits were prepared from the control (0\% BPF containing wheat flour) and composite flour samples (BPF10, BPF20 and BPF30) following the method given by Kaur et al. [19] with slight modification. Ingredients for biscuit preparation like butter, sugar, salt and sodium bicarbonate were also purchased from a local retail outlet (Malda, West Bengal, India). All the four flour samples (150 g) were mixed separately with butter $(40 \mathrm{~g})$, powdered sugar (35 g), salt ( $1 \mathrm{~g})$, sodium bicarbonate $(2 \mathrm{~g})$ and distilled water $(10 \mathrm{~mL})$. The mixture was kneaded until a soft and smooth dough was formed. The dough was then rolled on a flat rolling board to a uniform thickness of approximately $0.7 \mathrm{~cm}$ using a wooden rolling pin. Circular biscuits of $4.5 \mathrm{~cm}$ diameter were cut using a cookie cutter, placed on lightly greased trays and baked at $180^{\circ} \mathrm{C}$ for $15 \mathrm{~min}$ in a pre-heated convection oven (LG Electronics, India). After baking, all the biscuits were stored in airtight containers for further experiments.

\subsection{Physicochemical properties of composite flours and biscuits}

The moisture content of the flours and biscuits was analysed according to AACC-approved methods [20]. For determination of ash value, $2 \mathrm{~g}$ of sample was weighed in a previously ignited silica crucible and incinerated in a muffle furnace at $600{ }^{\circ} \mathrm{C}$ for $5 \mathrm{~h} \mathrm{[21].} \mathrm{Bulk} \mathrm{density} \mathrm{and}$ tapped density were determined by taking $10 \mathrm{~g}$ of flour samples separately in measuring cylinders. The initial volume was recorded for the calculation of bulk density. The samples were then tapped until no further reduction in volume, which was used for the calculation of tapped density. For the determination of water absorption capacity (WAC) and oil absorption capacity (OAC), $1 \mathrm{~g}$ of flour samples was mixed with $10 \mathrm{~mL}$ distilled water (for WAC) and $10 \mathrm{~mL}$ vegetable oil (for $\mathrm{OAC}$ ) and were kept at room temperature for $30 \mathrm{~min}$. The mixtures were then centrifuged at $5000 \mathrm{rpm}$ for $10 \mathrm{~min}$. After centrifugation, the supernatant was decanted and the tubes were inverted on a paper towel for $5 \mathrm{~min}$. WAC and OAC were determined by weighing the residues and expressed as percentage of water or oil absorbed per gram of samples, respectively.

Diameter and thickness of the biscuits were recorded using a Vernier caliper. The spread ratio of the biscuits was represented as the factor of diameter and thickness. Total protein content of the biscuits was estimated following the standard protocol [22]. Extraction and estimation of total sugars and reducing sugars were performed following previously described protocols [23, 24]. Extraction and estimation of proline were done following a slightly modified protocol of Bates et al. [25]. $0.5 \mathrm{~g}$ of biscuit samples was crushed with $3 \%$ aqueous sulfosalicylic acid and centrifuged at $8000 \mathrm{rpm}$ for $10 \mathrm{~min}$. The reaction mixture was prepared by adding $1 \mathrm{~mL}$ of extracted solution with $2 \mathrm{~mL}$ of glacial acetic acid and $2 \mathrm{~mL}$ of acidic ninhydrin. The mixture was then heated in a boiling water bath for $1 \mathrm{~h}$, cooled on an ice bath and finally vigorously shaken with $4 \mathrm{~mL}$ of toluene. The toluene layer was separated, and the absorbance was read at $520 \mathrm{~nm}$ for the determination of the concentration of proline using a standard curve.

\subsection{Pasting properties of the composite flours}

Pasting properties of the flour samples were determined using a Rapid Visco Analyser (Model: RVA-Techmaster, Newport Scientific, Australia).

\subsection{Colour and texture analysis of the biscuits}

Colour of the baked biscuits was read using a Hunter Lab Colorimeter (D-65, Hunter Associated Laboratory, USA). The colorimeter was calibrated by Hunter colour standards 
before the analysis of biscuit samples [26]. Texture analysis of the baked biscuits was performed in terms of breaking strength analysis using a texture analyser (UTM, Lloyd LR-5 K, Hampshire, UK).

\subsection{Quantification of antioxidants and free radical scavenging activity}

The quantification of the antioxidants and free radical scavenging assays of the biscuits were performed with the freeze-dried extracts of the biscuit samples. Briefly, the samples were extracted with methanol in a Soxhlet extractor, and the residue was concentrated using a rotary vacuum evaporator. For estimation of total phenol content, Folin-Ciocalteu method was followed [27]. Total flavonoid content was estimated using aluminium chloride method [28]. Estimation of ascorbate was done following the DNPH method with slight modification [29]. $1 \mathrm{~g}$ of biscuit sample was crushed with $6 \%$ trichloroacetic acid and centrifuged at $10,000 \mathrm{rpm}$ for $10 \mathrm{~min}$. After that, $2 \mathrm{~mL}$ of $2 \%$ dinitrophenyl hydrazine was added to $4 \mathrm{ml}$ of extract and kept in a boiling water bath for $10 \mathrm{~min}$. After cooling, $5 \mathrm{~mL}$ of sulphuric acid $80 \% \mathrm{v} / \mathrm{v}$ ) was added and the absorbance was read at $530 \mathrm{~nm}$. The amount of ascorbate was calculated using a standard curve of L-ascorbic acid. Estimation of tannin content was performed following vanillin-HCL assay [30]. Colorimetric estimation of the total saponin content was determined by a vanillin-sulphuric acid method [31]. Estimation of alkaloids was done following a modified protocol of Harborne [23]. Briefly, $5 \mathrm{~g}$ of sample was mixed with $200 \mathrm{~mL}$ of acetic acid and allowed to stand for $4 \mathrm{~h}$. The extract was filtered and concentrated on a water bath to one-fourth of the original volume. After that, ammonia solution was added dropwise until the precipitation was completed. The precipitate was collected, washed with dilute ammonium hydroxide and then airdried to obtain the weight of alkaloids.

Free radical scavenging activities of the biscuit samples were expressed as curcumin equivalents, except in case of FRAP assay. DPPH radical scavenging assay was performed following the standard protocol [32]. $\mathrm{ABTS}^{+}$cation scavenging assay was performed according to a standard protocol of Re et al. [33]. Nitric oxide radical scavenging assay was performed based on Griess-llosvay reaction [34]. Hydroxyl radical scavenging assay was performed following a standard protocol [35]. FRAP assay was performed by using ferric chloride method, and the activity was calculated from the standard curve of $\mathrm{FeSO}_{4}$ [36].

\subsection{Sensory evaluation of the biscuits}

Sensory evaluation of the samples was carried within $24 \mathrm{~h}$ of baking following the ethical standards of the
Indian Council of Medical Research, New Delhi, India [37]. Approval was obtained from the Internal Ethics Committee of the University of Gour Banga, Malda, and the evaluation was performed adhering to the Declaration of Helsinki. Fifty untrained panellists ( 22 males and 28 females, age between 20 to 30 years) were recruited from the postgraduate students and research scholars of the University. For the selection of panellists, regular biscuit consumers were given priority, they were well informed and required consent was obtained for their participation. All four biscuit samples were simultaneously placed to all the consumers in a randomized manner. During the procedure, they were instructed to cleanse their mouths in between consuming each sample to minimize any residual effect. The responses of the individuals were obtained concerning physical appearance, colour, taste, aroma, crispiness and overall acceptability of the samples using a nine-point hedonic scale $(1=$ dislike extremely, $2=$ dislike very much, $3=$ dislike moderately, $4=$ dislike slightly, $5=$ neither like or dislike, $6=$ like slightly, $7=$ like moderately, $8=$ like very much, $9=$ like extremely).

\subsection{Statistical analysis}

All the experiments were performed in triplicate, except for the texture analysis $(n=5)$, colour analysis $(n=10)$ and sensory evaluation $(n=50)$. The experimental data were subjected to analysis of variance (one-way ANOVA) using statistical analysis software (IBM SPSS Statistics, version 21). Duncan's multiple range tests were used to determine the difference among means at the level of $p<0.05$.

\section{Results and discussion}

Biscuits or cookies prepared from different sources have been attempted to introduce novel admixtures of flavour, texture and nutritional qualities. In this connection, the underutilized fruits and vegetables have been explored, owing to their unique nutritional compositions. Asadi et al. (2020) reported enhanced fibre content and antioxidant activities in cookies substituted with flour from fruits of Manilkara zapota (Chiku) [38] Physicochemical, nutritional and sensory characteristics of the cookies were found to be improved by using composite flour substituted with amaranth flour [39]. Similarly, low-calorie- and high-fibrerich biscuits were prepared from wheat flour partially substituted with flour prepared from underground tubers of Helianthus tuberosus, an unconventional food crop [40]. Ho and Latif [41] showed that the overall nutritional quality and sensory parameters of cookies can be enriched by blending wheat flour with pitaya or dragon fruit (Hylocereus undatus) peel flour. Kim and Park observed desirable 
changes in quality in terms of colour, texture and sensory attributes in cookies prepared with lotus leaf powder [42]. Pasqualone et al. [43] reported significant increments in phenolic content, antioxidant activities and sensory qualities of biscuits fortified with grape marc extract. In the same way, biscuits prepared from acorn flours showed similar enhancements in nutritional qualities and antioxidative parameters [44]. Taking a cue from these studies, flour prepared from banana pseudostem core was evaluated in terms of their ability to enhance the antioxidative and nutritional attributes of the partially substituted wheat flour biscuits. At the same time, the present study was also attempted towards devising a strategy for the sustainable utilization of banana pseudostems, which are otherwise lost as agricultural waste.

\subsection{Physicochemical properties of the composite flour samples}

The moisture content of the unsubstituted wheat flour (0\% BPF, control) was found to be lowest compared to that of the substituted flours (Table 1). Percentage of moisture content significantly increased with an increasing proportion of banana pseudostem flour (BPF). A similar increase in moisture contents has been observed in cases of composite flours containing rice, cassava and groundnut, which might accelerate microbial growth and affect storage quality. However, further processing into final products can help minimize these adverse effects [45]. Total ash content also significantly increased with the increasing percentage of BPF, compared to control (Table 1). This may be due to the gradual increase in the amount of dietary fibres present in BPF, similarly as reported by the fortification of semolina durum flour with legume flours [46].

High water absorption capacity (WAC) may infer the presence of hydrophilic components, viz. carbohydrates and proteins, and influence the cohesiveness of the food products [47]. In the present study, WAC of the control was lowest $(82 \pm 3 \%)$ among all the flour samples and a significant increase was observed with the substitution with BPF flour (Table 1). Akoja and Coker have also reported a similar increase in WAC of composite flour blended with okra powder and correlated this with enhanced starch and fibre content of the samples [48]. However, subsequent baking at a higher temperature could effectively reduce the water absorption capacity. Oil absorption capacity (OAC) also showed a similar trend, though the control $(85 \pm 4.6 \%)$ and BPF10 $(90.33 \pm 2.5 \%)$ samples did not exhibit any significant differences (Table 1). Bulk density and tapped density were measured to analyse the consolidation and flowability of the flour samples [49]. Moreover, these parameters also affect the hydration rate during baking. Bulk and tapped density were found to be significantly decreased with the increasing amount of BPF, indicating relatively good packaging characteristics of the flour particles and less flowability of the sample (Table 1).
Table 1 Physicochemical and pasting properties of the partially substituted banana pseudostem flour (BPF)

\begin{tabular}{|c|c|c|c|c|}
\hline Parameters & Control* & BPF10 & BPF20 & BPF30 \\
\hline \multicolumn{5}{|l|}{ Physicochemical characteristics } \\
\hline Moisture (\%) & $0.12 \pm 0.01^{\mathrm{a} * *}$ & $0.1 \pm 0.03^{\mathrm{a}}$ & $0.13 \pm 0.09^{\mathrm{a}}$ & $0.14 \pm 0.05^{\mathrm{a}}$ \\
\hline Ash content (\%) & $1.05 \pm 0.13^{\mathrm{a}}$ & $1.25 \pm 0.53^{\mathrm{a}}$ & $1.98 \pm 0.33^{b}$ & $2.55 \pm 0.1^{b}$ \\
\hline Water absorption capacity (\%) & $82.33 \pm 3.06^{\mathrm{a}}$ & $106.67 \pm 4.73^{b}$ & $122.33 \pm 3.51^{c}$ & $137.67 \pm 3.79^{d}$ \\
\hline Oil absorption capacity (\%) & $85 \pm 4.58^{\mathrm{a}}$ & $90.33 \pm 2.52^{\mathrm{a}}$ & $100.67 \pm 4.16^{b}$ & $119.67 \pm 0.58^{c}$ \\
\hline Bulk density $\left(\mathrm{g} / \mathrm{cm}^{3}\right)$ & $0.53 \pm 0.02^{d}$ & $0.5 \pm 0.01^{c}$ & $0.45 \pm 0.01^{b}$ & $0.43 \pm 0.01^{\mathrm{a}}$ \\
\hline Tapped density $\left(\mathrm{g} / \mathrm{cm}^{3}\right)$ & $0.67 \pm 0.03^{c}$ & $0.63 \pm 0.05^{b}$ & $0.59 \pm 0.01^{\mathrm{ab}}$ & $0.53 \pm 0.01^{\mathrm{a}}$ \\
\hline \multicolumn{5}{|l|}{ Pasting properties (RVA analysis) } \\
\hline Peak viscosity (mPa.s) & $3154 \pm 49.93^{d}$ & $2853.67 \pm 59.72^{c}$ & $2539.33 \pm 25.66^{\mathrm{b}}$ & $2095.33 \pm 8.5^{\mathrm{a}}$ \\
\hline Trough viscosity (mPa.s) & $2059 \pm 15^{d}$ & $1857 \pm 63.02^{c}$ & $1523 \pm 38.74^{b}$ & $1332 \pm 26.63^{\mathrm{a}}$ \\
\hline Breakdown (mPa.s) & $1095 \pm 39.24^{c}$ & $996.67 \pm 44.77^{b}$ & $1016.33 \pm 31.21^{\mathrm{b}}$ & $763.33 \pm 23.03^{\mathrm{a}}$ \\
\hline Final viscosity (mPa.s) & $3752.33 \pm 19.09^{d}$ & $3146.33 \pm 41.68^{c}$ & $2617 \pm 21.63^{b}$ & $2333.67 \pm 3.21^{\mathrm{a}}$ \\
\hline Setback (mPa.s) & $1693.33 \pm 22.01^{d}$ & $1289.33 \pm 49.17^{c}$ & $1094 \pm 19.92^{\mathrm{b}}$ & $1001.67 \pm 29.01^{\mathrm{a}}$ \\
\hline Peak time (min) & $6.24 \pm 0.1^{b}$ & $6.38 \pm 0.08^{b}$ & $6.18 \pm 0.08^{b}$ & $5.91 \pm 0.14^{\mathrm{a}}$ \\
\hline Pasting temperature $\left({ }^{\circ} \mathrm{C}\right)$ & $68.03 \pm 0.06^{\mathrm{a}}$ & $70.78 \pm 0.49^{b}$ & $71.28 \pm 0.06^{\mathrm{b}}$ & $72.48 \pm 0.98^{c}$ \\
\hline
\end{tabular}

${ }^{*}$ Control, BPF10, BPF20, BPF30-Composite flours prepared by substituting $0 \%, 10 \%, 20 \%$ and $30 \%$ wheat flour with banana pseudostem core flour, respectively

**Values represent mean \pm SD $(n=3)$ followed by lowercase letters in superscript. Different letters $(a-d)$ within the row indicate significant differences in the mean values following post hoc analysis by Duncan's test at $p<0.05$ 


\subsection{Pasting properties of the composite flour samples}

Pasting property of flour samples affects the texture and overall digestibility of processed food products and is regarded as an important criterion predetermining quality and aesthetics in the food industry [50]. The pasting property of the composite flour samples is listed in Table 1. Incorporation of BPF into wheat flour significantly reduced all the parameters except pasting temperature, which was found to be significantly higher in the BPF-substituted flours (10\%, 20\% and 30\%). Higher pasting temperature may confer higher water-binding capacity, higher gelatinization tendency and lower swelling property [51]. Concentration-dependent decrease in all the viscosity parameters (peak, trough, breakdown, final and setback) could be due to the complex interaction between proteins, fats and carbohydrates during the heating-cooling phase of RVA. This decrease might be advantageous in further processing of the composite flours due to greater resistance against heating and shearing [52]. Similar changes in pasting properties were also observed in a previous study where wheat flour was substituted with chickpea flour [53].

\subsection{Physicochemical properties of biscuits}

It was observed that the substitution of wheat flour by BPF enhanced the moisture content. However, after baking, the moisture content of the partially substituted BPF biscuits significantly decreased in comparison with the control sample (Table 2). This indicated an increase in the relative shelf life of the BPF-substituted biscuits post-baking. A similar decrease in moisture content was observed in gluten-free biscuits prepared from buckwheat flour [54]. Ash content in food products gives an idea of the presence of mineral elements [55]. A significant enhancement in ash content of the BPF-fortified biscuits (about 2.1-fold, 2.5fold and 3.14-fold in BPF10, BPF20 and BPF30, respectively) compared to the control sample was observed (Table 2). In terms of weight loss after baking, BPF20 and BPF30 biscuits showed a significant loss in comparison with the control (about twofold and 1.8-fold, respectively) (Table 2). The weight loss of the BPF biscuits can be attributed to the concomitant loss of moisture during the baking process. The diameter of all the biscuits post-baking remained almost unchanged, whereas the thickness of the BPF biscuits was found to be significantly lower compared to control (about 1.03-fold, 1.07-fold and 1.1-fold for BPF10, BPF20 and BPF30, respectively) (Table 2). Spread ratio of all the BPF biscuits, therefore, showed significant increments (about 1.02-fold, 1.05-fold and 1.09-fold in BPF10, BPF20 and BPF30, respectively) from the control. According to Chauhan et al. [39], such increase in spread ratio could be influenced by the presence of higher amounts of non-wheat proteins in the composite flours, which has also been considered as a desirable trait for biscuits. These findings are in agreement with the results of Bala et al. [56], who also observed similar changes in diameter, thickness and spread ratio of cookies prepared from wheat flour supplemented with cassava and water chestnut flours.

It was also important to assess the nutritional aspects of the biscuits. In this connection, quantification of protein,
Table 2 Physicochemical and functional properties of the banana pseudostem flour (BPF)-substituted wheat flour biscuits
SN Applied Sciences
A SPRINGER NATURE journal

\begin{tabular}{|c|c|c|c|c|}
\hline Parameters & Control* & BPF10 & BPF20 & BPF30 \\
\hline \multicolumn{5}{|l|}{ Physical and functional aspects } \\
\hline Moisture content (\%) & $2.24 \pm 0.05^{\mathrm{b} * *}$ & $1.93 \pm 0.08^{\mathrm{a}}$ & $2.02 \pm 0.08^{\mathrm{a}}$ & $2.01 \pm 0.16^{\mathrm{a}}$ \\
\hline Ash content (\%) & $0.91 \pm 0.05^{\mathrm{a}}$ & $1.89 \pm 0.15^{b}$ & $2.27 \pm 0.2^{c}$ & $2.83 \pm 0.12^{d}$ \\
\hline Weight loss after baking (\%) & $18.37 \pm 3.73^{\mathrm{a}}$ & $24.61 \pm 7.08^{\mathrm{ab}}$ & $32.88 \pm 10.24^{b}$ & $36.03 \pm 2.94^{b}$ \\
\hline Diameter (cm) & $4.62 \pm 0.08^{\mathrm{a}}$ & $4.63 \pm 0.03^{\mathrm{a}}$ & $4.57 \pm 0.03^{\mathrm{a}}$ & $4.55 \pm 0.05^{\mathrm{a}}$ \\
\hline Thickness (cm) & $1.02 \pm 0.01^{d}$ & $0.99 \pm 0.02^{c}$ & $0.95 \pm 0.01^{b}$ & $0.92 \pm 0.01^{\mathrm{a}}$ \\
\hline Spread ratio & $4.53 \pm 0.09^{a}$ & $4.65 \pm 0.05^{b}$ & $4.79 \pm 0.006^{c}$ & $4.97 \pm 0.03^{d}$ \\
\hline \multicolumn{5}{|l|}{ Nutritional aspects*** $(\mathrm{g} / 100 \mathrm{~g})$} \\
\hline Protein & $7.25 \pm 0.22^{\mathrm{a}}$ & $13.15 \pm 0.21^{\mathrm{b}}$ & $15.23 \pm 0.23^{c}$ & $15.83 \pm 0.21^{d}$ \\
\hline Total sugars & $2.55 \pm 0.16^{\mathrm{a}}$ & $2.66 \pm 0.08^{\mathrm{a}}$ & $2.65 \pm 0.12^{\mathrm{a}}$ & $2.71 \pm 0.17^{\mathrm{a}}$ \\
\hline Reducing sugars & $1.01 \pm 0.12^{\mathrm{a}}$ & $0.83 \pm 0.08^{\mathrm{a}}$ & $0.83 \pm 0.06^{\mathrm{a}}$ & $0.94 \pm 0.09^{\mathrm{a}}$ \\
\hline Fats & $12.33 \pm 1.53^{b}$ & $8.68 \pm 0.29^{a}$ & $8.47 \pm 0.53^{\mathrm{a}}$ & $8.33 \pm 1.19^{a}$ \\
\hline Proline & $0.55 \pm 0.08^{\mathrm{a}}$ & $1.43 \pm 0.03^{b}$ & $1.67 \pm 0.02^{c}$ & $1.71 \pm 0.06^{\mathrm{c}}$ \\
\hline
\end{tabular}

*Control, BPF10, BPF20, BPF30—Composite flours prepared by substituting $0 \%, 10 \%, 20 \%$ and $30 \%$ wheat flour with banana pseudostem core flour, respectively

**Values represent mean \pm SD $(n=3)$ followed by lowercase letters in superscript. Different letters (a-d) with in the row indicate significant differences in the mean values following post hoc analysis by Duncan's test at $p<0.05$

***Nutritional aspects were calculated per $100 \mathrm{~g}$ actual weight of the biscuits 
fats, proline, total and reducing sugar contents in the biscuit samples was performed. Protein content was found to increase in a concentration-dependent manner in BPF-fortified biscuits in comparison with control (about 1.8-2.2-fold increase) (Table 2). The fat content of all the BPF biscuits was also significantly low compared to control (Table 2). Such high protein and less fat content of the BPF-substituted biscuits can be considered nutritionally beneficial over wheat flour products [57]. Significant increase in proline content was also observed in the

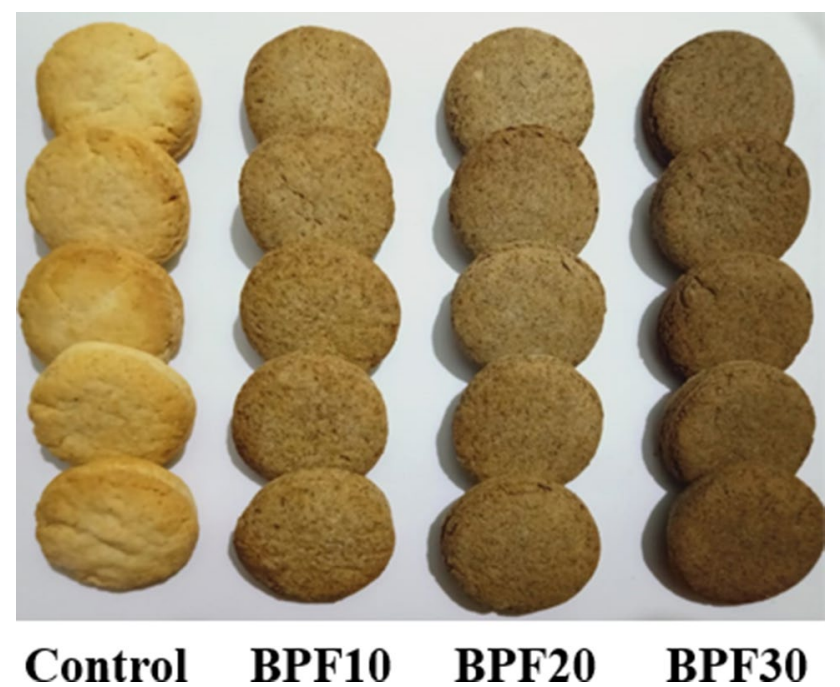

Fig. 2 Physical appearance of biscuits (Control, BPF10, BPF20, BPF30) prepared with unsubstituted wheat flour $(0 \%)$, and $10 \%$, $20 \%$ and $30 \%(\mathrm{w} / \mathrm{w})$ banana pseudostem core substituted composite flours
BPF-substituted biscuits (about 2.6-3.1-fold increase), referring to the presence of a considerably high amount of free amino acid content in comparison with the control (Table 2). However, no absolute changes in the amount of total and reducing sugars in the BPF-fortified biscuits were observed (Table 2). These changes in amino acid and sugar content were probably caused due to acceleration of Maillard reaction and were also observed in biscuits prepared from composite flours of sunflower seed and wheat [58].

\subsection{Colour and texture attributes of biscuits}

Colour analysis presents an important criterion for the overall acceptability of the baked products for consumption. Maillard reaction between protein and reducing sugars during baking primarily controls the development of colour [59]. In the present study, the colour attributes of the biscuit samples differed significantly, as can be observed superficially (Fig. 2). This was also validated by the colour analysis of the samples. In this connection, $L^{*}$ value decreased about 1.8-, 1.3- and 1.2-fold in case of BPF30, BPF20 and BPF10 biscuits, respectively, in comparison with control (Table 3). The result is in accordance with that obtained by Sibian and Riar in composite flour cookies prepared by admixtures of kidney bean, chickpea and wheat [60]. Furthermore, significant concentrationdependent decrease in the $b^{*}$ value was found in the BPF biscuits in comparison with control (Table 3 ). Colour changes in biscuits or cookies result due to degradation of pigments or formation of any brown coloured pigments during the convection process [61]. Moreover, enzymatic browning of the banana pseudostem flour, which may

Table 3 Colour and texture analysis of the banana pseudostem flour (BPF)-substituted wheat flour biscuits

\begin{tabular}{|c|c|c|c|c|}
\hline Parameters & Control* & BPF10 & BPF20 & BPF30 \\
\hline \multicolumn{5}{|l|}{ Colour } \\
\hline$L^{*}$ & $73.18 \pm 3.92^{\mathrm{d} * *}$ & $52.69 \pm 1.6^{c}$ & $49.28 \pm 2.73^{b}$ & $40.35 \pm 3.27^{a}$ \\
\hline$a^{*}$ & $6.92 \pm 3.04^{\mathrm{a}}$ & $7.12 \pm 0.76^{\mathrm{a}}$ & $6.31 \pm 0.81^{\mathrm{a}}$ & $7.22 \pm 0.31^{\mathrm{a}}$ \\
\hline$b^{*}$ & $30.49 \pm 3.22^{d}$ & $23.26 \pm 2.14^{c}$ & $19.28 \pm 0.95^{b}$ & $16.74 \pm 1.98^{\mathrm{a}}$ \\
\hline$\Delta E$ & - & $22.08 \pm 3.13^{\mathrm{a}}$ & $27.18 \pm 4.38^{b}$ & $35.95 \pm 4.44^{c}$ \\
\hline$\underline{h}\left({ }^{\circ}\right)$ & $77.66 \pm 4.43^{c}$ & $73 \pm 0.76^{b}$ & $71.89 \pm 1.99^{\mathrm{b}}$ & $66.43 \pm 2.84^{\mathrm{a}}$ \\
\hline$C$ & $31.35 \pm 3.75^{c}$ & $24.32 \pm 2.25^{b}$ & $20.29 \pm 1.03^{\mathrm{a}}$ & $18.25 \pm 1.79^{\mathrm{a}}$ \\
\hline$s$ & $0.43 \pm 0.07^{\mathrm{ab}}$ & $0.46 \pm 0.04^{b}$ & $0.41 \pm 0.03^{\mathrm{a}}$ & $0.45 \pm 0.02^{\mathrm{ab}}$ \\
\hline \multicolumn{5}{|l|}{ Texture } \\
\hline Hardness $(N)$ & $23.9 \pm 9.28^{\mathrm{a}}$ & $53.29 \pm 13.25^{b}$ & $58.54 \pm 4.33^{b}$ & $90.06 \pm 14.49^{c}$ \\
\hline Fracturability $(\mathrm{mm})$ & $3.55 \pm 0.82^{b}$ & $2.64 \pm 0.89^{\mathrm{ab}}$ & $2.4 \pm 0.63^{\mathrm{a}}$ & $2.87 \pm 0.52^{\mathrm{ab}}$ \\
\hline Stiffness $(\mathrm{N} / \mathrm{mm})$ & $27,260.18 \pm 10,131.69^{a}$ & $74,529.19 \pm 9495.35^{a}$ & $61,899.3 \pm 9637.79^{a}$ & $97,136.89 \pm 13,411.25^{a}$ \\
\hline
\end{tabular}

${ }^{*}$ Control, BPF10, BPF20, BPF30-Composite flours prepared by substituting $0 \%, 10 \%, 20 \%$ and $30 \%$ wheat flour with banana pseudostem core flour, respectively

**Values represent mean \pm SD ( $n=10$ for colour and 5 for texture) followed by lowercase letters in superscript. Different letters (a-d) within the row indicate significant differences in the mean values following post hoc analysis by Duncan's test at $p<0.05$ 
result due to the oxidation of phenolics by polyphenol oxidase, may also contribute to the browning of the baked biscuits [62]. The increase in brown pigments, in turn, could be attributed to the enhanced antioxidative activity of the baked products [63]. In the present study, the decrease in $L^{*}$ and $b^{*}$ values in BPF biscuits led to infer that the incorporation of BPF in wheat flour reduced the lightness and yellowness of the biscuit colour. Significant changes in the colour difference $(\Delta E)$ values of the BPFsubstituted biscuits from the control also corroborated with the changes in the $L^{*}$ and $b^{*}$ values. Such high colour difference values could be developed due to ingredient composition and pigmentation, which in turn depend on the content of reducing sugar, proteins or amino acids present on the surface, baking temperature and time [62]. In our study, the hue values ranged from $66.42^{\circ}$ to $77.66^{\circ}$, showing gradual changes from yellow to orange in accordance with the increasing percentage of BPF (Table 3). Similarly, chroma $\left(C^{*}\right)$ of the biscuits was also found to be lowered with increasing concentration of $B P F$, indicating the decrease in brightness of the BPF biscuits compared to control (Table 3). However, the colour saturation values $(s)$ of all the samples were found to remain almost unchanged. Similar changes were also observed in biscuits made from wheat flour mixed with flours obtained from banana pulp and prickly pear [62].

A concentration-dependent rise in hardness and stiffness of the BPF-substituted biscuits in comparison with control was observed (Table 3). Significant increments in the hardness of BPF biscuits could be attributed to its lower moisture contents, which may in turn affect the acceptability in terms of enhancing the crunchiness [54]. Previous studies with beetroot leaf powder-substituted wheat flour cookies also showed similar enhancements in hardness and stiffness [61]. According to De Simas et al. [64], the hardness of the cookies results due to extensive hydrogen bond formation between starch and protein during dough making and baking. Several other factors, viz. higher protein and fibre content, and higher water absorption capacity, may be responsible for increased hardness. Also in our study, 2.27-3.56-fold enhancements in stiffness of the BPF-substituted biscuits from the control sample were observed; however, the changes were not significant. Further, no significant changes in fracturability except for BPF20 biscuits were observed, where it showed a significant decrease (about 1.5-fold) from control (Table 3).

\subsection{Antioxidant properties}

The presence of phenolics, flavonoids and other antioxidant molecules in baked products have been considered advantageous owing to their nutraceutical properties [65].
In the present study, the substitution of BPF in the wheat flour biscuits gradually enhanced the total phenolic and flavonoid contents in a concentration-dependent manner (Table 4). BPF30 biscuits were found to contain the highest amount of phenol and flavonoid ( $292.5 \mathrm{mg}$ gallic acid equivalent $/ 100 \mathrm{~g}$ and 209.93 quercetin equivalent/100 g), that accounted for about 2.6- and 2.1-fold increase from the control. Similarly, tannin content was found to be significantly increased in all the BPF-substituted biscuits (Table 4). This type of enhancement in total phenolic content in the biscuits prepared from unconventional flours of purple sweet potato and kale has been reported previously [66]. A significant increase of about 1.05 -fold and 1.15-fold in ascorbate content was observed in BPF20 and BPF30, compared to control (Table 4). Alkaloid content also gradually increased in the BPF-substituted biscuits; however, only BPF30 biscuits showed a significant increase (about 2.7-fold) from the control (Table 4). On the other hand, a concentration-dependent reduction in the saponin content was observed in all the BPF-substituted biscuits (Table 4).

The presence of antioxidant molecules in the baked products is often associated with an increase in the free radical scavenging properties [67]. The enhancement of free radical scavenging properties in the biscuits would therefore be of immense importance from the viewpoint of consumption. In the present study, DPPH radical scavenging activity of the biscuit samples increased in a concentration-dependent manner with an increasing amount of BPF; however, the control sample did not exhibit any activity (Table 4). In ABTS cation scavenging assay, BPF10 showed about 1.9-fold increase from that of the control (Table 4). A further increase was also found in BPF20 and BPF30 samples (about 2.9-fold in both cases). The pattern of scavenging followed almost a similar trend in cases of $\mathrm{NO}$ and $\mathrm{OH}$ scavenging assay (Table 4). Also, a concentration-dependent increase in FRAP activity was observed with the substitution of BPF, but significant increase was observed only in BPF20 and BPF30 samples (2.6- and 3.2fold increase from the control, respectively) (Table 4). Previous studies have reported the enhancements in free radical scavenging activities of wheat flour cookies supplemented with tomato powder and crude lycopene [68]. Similarly, Jan et al. [63] also observed similar increments in antioxidative activities of gluten-free cookies prepared from raw and germinated Chenopodium album flour.

\subsection{Sensory evaluation of the biscuits}

Sensory evaluation of the biscuit samples for the assessed parameters more or less varied significantly (Fig. 3). Individually, the physical appearance of the BPF biscuits showed a decrease of 1.07-, 1.19- and 1.2-fold (BPF10, 
Table 4 Quantitation of some antioxidant molecules and free radical scavenging properties of the banana pseudostem flour (BPF)-substituted wheat flour biscuits

\begin{tabular}{|c|c|c|c|c|}
\hline Parameters & Control* & BPF10 & BPF20 & BPF30 \\
\hline \multicolumn{5}{|l|}{ Antioxidant biomolecules** } \\
\hline Total phenol (mg gallic acid equiv./100 g) & $113.75 \pm 5.5^{\mathrm{a} * * *}$ & $171.81 \pm 20.9^{b}$ & $269.07 \pm 8.64^{c}$ & $292.51 \pm 7.25^{d}$ \\
\hline Total flavonoid (mg quercetin equiv./100 g) & $97.59 \pm 5.67^{\mathrm{a}}$ & $154.49 \pm 6.75^{\mathrm{b}}$ & $193.11 \pm 6.53^{c}$ & $209.94 \pm 4.82^{d}$ \\
\hline Tannin (mg tannic acid equiv./100 g) & $34.03 \pm 2.19^{\mathrm{a}}$ & $66.46 \pm 5.29^{b}$ & $80.05 \pm 2.94^{c}$ & $73.51 \pm 3.32^{c}$ \\
\hline Ascorbate $(\mathrm{mg} / 100 \mathrm{~g})$ & $74.49 \pm 0.83^{\mathrm{a}}$ & $71.75 \pm 1.93^{\mathrm{a}}$ & $78.74 \pm 0.99^{b}$ & $85.31 \pm 2.22^{c}$ \\
\hline Saponin (mg diosgenin equiv./100 g) & $509 \pm 68.71^{a}$ & $395.82 \pm 52.67^{b}$ & $157.64 \pm 23.41^{c}$ & $68.84 \pm 12.62^{d}$ \\
\hline Alkaloid (mg/100 g) & $26.67 \pm 5.77^{\mathrm{a}}$ & $36.67 \pm 11.55^{\mathrm{a}}$ & $53.33 \pm 20.82^{\mathrm{a}}$ & $73.33 \pm 15.28^{b}$ \\
\hline \multicolumn{5}{|l|}{ Free radical scavenging ${ }^{* * * *}$} \\
\hline $\mathrm{DPPH}(\mathrm{mM} C E / g)^{5}$ & n.d & $0.44 \pm 0.14^{\mathrm{a}}$ & $1.31 \pm 0.21^{\mathrm{b}}$ & $2.08 \pm 0.19^{c}$ \\
\hline ABTS (mM CE/g) & $4.62 \pm 0.19^{\mathrm{a}}$ & $7.46 \pm 0.87^{b}$ & $9.85 \pm 0.04^{c}$ & $9.66 \pm 0.04^{c}$ \\
\hline $\mathrm{NO}(\mathrm{mM} C E / \mathrm{g})$ & $4.77 \pm 0.13^{\mathrm{a}}$ & $4.99 \pm 0.09^{\mathrm{ab}}$ & $5.1 \pm 0.13^{b}$ & $6.41 \pm 0.11^{c}$ \\
\hline $\mathrm{OH}(\mathrm{mM} C E / \mathrm{g})$ & $0.9 \pm 0.82^{\mathrm{a}}$ & $12.7 \pm 1.38^{\mathrm{b}}$ & $9.64 \pm 1.17^{c}$ & $14.99 \pm 0.43^{d}$ \\
\hline $\mathrm{FRAP}\left(\mathrm{mM} \mathrm{Fe}^{2+} / \mathrm{g}\right)$ & $0.21 \pm 0.07^{\mathrm{a}}$ & $0.35 \pm 0.08^{\mathrm{ab}}$ & $0.41 \pm 0.09^{b}$ & $0.48 \pm 0.09^{b}$ \\
\hline
\end{tabular}

${ }^{*}$ Control, BPF10, BPF20, BPF30-Composite flours prepared by substituting $0 \%, 10 \%, 20 \%$ and $30 \%$ wheat flour with banana pseudostem core flour, respectively

**Quantification of antioxidant biomolecules was done per $100 \mathrm{~g}$ actual weight of the biscuits

***Values represent mean \pm S.D. ( $n=10$ for colour and 5 for texture) followed by lowercase letters in superscript. Different letters (a-d) with in the row indicate significant differences in the mean values following post hoc analysis by Duncan's test at $p<0.05$

****Free radical scavenging activities were performed from the freeze-dried methanolic extracts and finally calculated as mM curcumin equivalent (CE) or $\mathrm{mM} \mathrm{Fe}^{2+}$ per $1 \mathrm{~g}$ actual weight of the biscuits

BPF20, BPF30, respectively) from control. Colour and aroma of the BPF biscuits also showed a similar pattern of decrease from the control sample. Taste attribute of the BPF20 and BPF30 biscuits declined by about 1.06and 1.17-fold, respectively. More importantly, the taste attribute of the BPF10 biscuits did not change significantly from the control. In terms of crispiness, a similar trend was observed, where BPF10 biscuits did not show any observable difference from the control. Also, the overall acceptability of the BPF biscuits showed a significant decrease from the control. However, only 1.04- and 1.08fold decrease in the overall acceptability of the BPF10 and BPF20 biscuits from the control seems reasonable. These results are in accordance with the previous studies with banana pseudostem incorporated wheat flour cookies by Ambrose and Lekshman [69].

\section{Conclusion}

The biscuits supplemented with BPF constitutes several bioactive compounds like phenolics, flavonoids, ascorbate, proline, etc. and also showed promising free radical scavenging properties. High protein, low fat and low sugar content of the BPF biscuits are equally important for their dietary and health benefits. Low moisture and high ash content of the biscuits along with high pasting temperature and low viscosity of the BPF-substituted flours also

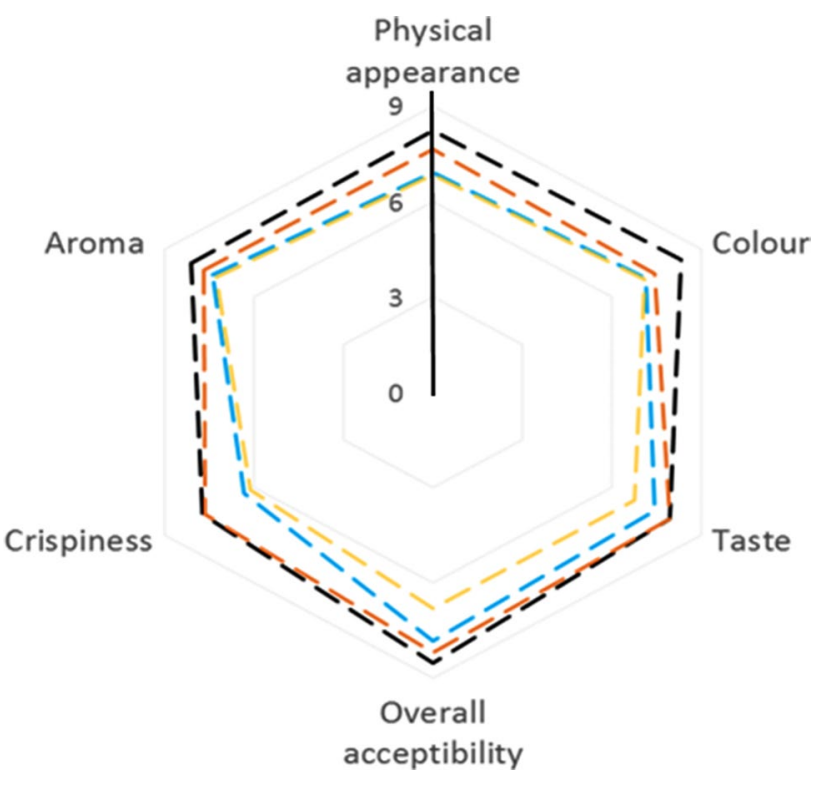

Fig. 3 Radar plot depicting the sensory characteristics of biscuits (- Control, - - BPF10, - - BPF20, - - BPF30) prepared with unsubstituted wheat flour $(0 \%), 10 \%, 20 \%$ and $30 \%(\mathrm{w} / \mathrm{w})$ banana pseudostem core flour-substituted composite flours. Values represent the average of 50 replicates based up on a nine-point hedonic scale

confer relatively longer shelf life and good storage characteristics. Moreover, sensory characteristics of the biscuits were moderately acceptable, especially the BPF10 and 
BPF20 biscuits. Enrichment in the taste and overall acceptability could be enhanced with some modifications in the biscuit composition. Further studies on the simulated gastrointestinal digestion of the BPF biscuits in future will be carried out to present an accurate picture of the nutritional and health benefits. This study therefore presents a feasible option for the utilization of banana pseudostem waste in a very simple and effective manner.

Acknowledgements The authors would like to acknowledge the financial and infrastructural support of the University of Gour Banga, Malda, India. The authors also acknowledge CSIR-Central Food Technological Research Institute for colour and texture analysis; and ICAR-Central Institute of Post-Harvest Engineering and Technology for RVA analysis.

Author contributions Rakhi Chakraborty, Swarnendu Roy and Sukanta Majumdar performed conceptualization; Sanjida Sabruna and Rumeli Roy contributed to methodology; Rakhi Chakraborty and Swarnendu Roy done a writing-original draft preparation; Rakhi Chakraborty, Swarnendu Roy and Sukanta majumdar done a writing-review and editing; Sanjida Sabruna and Rumeli Roy was involved in formal analysis and investigation; Swarnendu Roy supervised the article.

Funding The work presented in this manuscript did not receive any grants or funding from any Government agencies or not-for-profit organizations.

\section{Compliance with ethical standards}

Conflict of interest The authors declare no conflict of interest.

Ethical approval All the necessary guidelines for sensory evaluation have been followed, and approval was obtained from the Internal Ethics Committee of University of Gour Banga, Malda, India.

Open Access This article is licensed under a Creative Commons Attribution 4.0 International License, which permits use, sharing, adaptation, distribution and reproduction in any medium or format, as long as you give appropriate credit to the original author(s) and the source, provide a link to the Creative Commons licence, and indicate if changes were made. The images or other third party material in this article are included in the article's Creative Commons licence, unless indicated otherwise in a credit line to the material. If material is not included in the article's Creative Commons licence and your intended use is not permitted by statutory regulation or exceeds the permitted use, you will need to obtain permission directly from the copyright holder. To view a copy of this licence, visit http://creativecommons .org/licenses/by/4.0/.

\section{References}

1. Pareek S (2016) Nutritional and biochemical composition of banana (Musa spp.) cultivars. In: Simmonds MSJ, Preedy VR (eds) Nutritional composition of fruit cultivars. Academic Press, San Diego, pp 49-81
2. Lebaka VR, Wee YJ, Narala VR, Joshi VK (2018) Development of new probiotic foods-a case study on probiotic juices. In: Grumezescu AM, Holban AM (eds) Therapeutic, probiotic, and unconventional foods. Academic Press, San Diego, pp 55-78

3. Borborah K, Borthakur SK, Tanti B (2016) Musa balbisiana Colla-taxonomy, traditional knowledge and economic potentialities of the plant in Assam, India. Indian J Tradit Know 15:116-120

4. Horticulture Statistics Division (2018) Horticultural Statistics at a Glance 2018. Ministry of Agriculture \& Farmers'Welfare, Government of India

5. Rochana A, Dhalika T, Budiman A, Kamil KA (2017) Nutritional value of a banana stem (Musa paradisiaca Val) of anaerobic fermentation product supplemented with nitrogen, sulphur and phosphorus sources. Pak J Nutr 16:738-742. https://doi. org/10.3923/pjn.2017.738.742

6. Saravanan K, Aradhya SM (2011) Polyphenols of pseudostem of different banana cultivars and their antioxidant activities. J Agr Food Chem 59:3613-3623. https://doi.org/10.1021/jf103 $835 z$

7. Dikshit P, Tyagi MK, Shukla K, Gambhir JK, Shukla R (2016) Antihypercholesterolemic and antioxidant effect of sterol rich methanol extract of stem of Musa sapientum (banana) in cholesterol fed wistar rats. J Food Sci Technol 53:1690-1697. https://doi. org/10.1007/s13197-015-2096-5

8. Abdel Ghany TM, Ganash M, Alawlaqi MM, Al-Rajhi AMH (2019) Antoixidant, antitumor, antimicrobial activities evaluation of Musa paradisiaca L. pseudostem exudate cultivated in Saudi Arabia. BioNanoSci 9:172-178. https://doi.org/10.1007/s1266 8-018-0580-x

9. Sharma M, Patel SN, Sangwan RS, Singh SP (2017) Biotransformation of banana pseudostem extract in to a functional juice containing value added biomolecules of potential health benefits. Indian J Exp Biol 55:453-462

10. Padam BS, Tin HS, Chye FK, Abdullah MI (2014) Banana byproducts: an under-utilized renewable food biomass with great potential. J Food Sci Technol 51:3527-3545. https://doi. org/10.1007/s13197-012-0861-2

11. Ingale S, Joshi SJ, Gupte A (2014) Production of bioethanol using agricultural waste: banana pseudo stem. Braz J Microbiol 45:885-892. https://doi.org/10.1590/s1517-838220140003000 18

12. Melini F, Melini V, Luziatelli F, Ruzzi M (2017) Current and forward-looking approaches to technological and nutritional improvements of gluten-free bread with legume flours: a critical review. Compr Rev Food Sci Food Saf 16:1101-1122. https:// doi.org/10.1111/1541-4337.12279

13. Julianti E, Rusmarilin H, Ridwansyah YE (2017) Functional and rheological properties of composite flour from sweet potato, maize, soybean and xanthan gum. J Saudi Soc Agric Sci 16:171177. https://doi.org/10.1016/j.jssas.2015.05.005

14. Chandra S, Singh S, Kumari D (2015) Evaluation of functional properties of composite flours and sensorial attributes of composite flour biscuits. J Food Sci Technol 52:3681-3688. https:// doi.org/10.1007/s13197-014-1427-2

15. Segundo C, Román L, Gómez M, Martínez MM (2017) Mechanically fractionated flour isolated from green bananas (M. cavendishii var. nanica) as a tool to increase the dietary fiber and phytochemical bioactivity of layer and sponge cakes. Food Chem 219:240-248. https://doi.org/10.1016/j.foodchem.2016.09.143

16. Agama-Acevedo E, Islas-Hernández JJ, Pacheco-Vargas G, Osorio-Díaz P, Bello-Pérez LA (2012) Starch digestibility and glycemic index of cookies partially substituted with unripe banana flour. LWT 46:177-182. https://doi.org/10.1016/j.lwt.2011.10.010

17. Khoozani AA, Kebede B, Bekhit AEA (2020) Rheological, textural and structural changes in dough and bread partially substituted 
with whole green banana flour. LWT 126:109252. https://doi. org/10.1016/j.lwt.2020.109252

18. Adeola AA, Ohizua ER (2018) Physical, chemical, and sensory properties of biscuits prepared from flour blends of unripe cooking banana, pigeon pea, and sweet potato. Food Sci Nutr 6:532-540. https://doi.org/10.1002/fsn3.590

19. Kaur M, Singh V, Kaur R (2017) Effect of partial replacement of wheat flour with varying levels of flaxseed flour on physicochemical, antioxidant and sensory characteristics of cookies. Bioact Carbohydr Diet Fibre 9:14-20. https://doi.org/10.1016/j. bcdf.2016.12.002

20. AACC International (2000) Approved methods of the AACC, 10th edn. American Association of Cereal Chemists, St. Paul, MN, USA

21. AOAC International (2000) Official methods of Analysis, 17th edn. Association of Official Analytical Chemists International, Gaithersburg, MD, USA

22. Lowry OH, Rosenbrough NJ, Farr AL, Randall RJ (1951) Protein measurement with Folin-Phenol reagent. J Biol Chem 193: 265-275. https://www.jbc.org/content/193/1/265.full.pdf

23. Harborne JB (1973) Phytochemical methods. Chapman and Hall Ltd., New York

24. Plummer DT (1978) An introduction to practical biochemistry, 2nd edn. Tata McGraw-Hill Publishing Co., New Delhi

25. Bates LS, Waldren RP, Teare ID (1973) Rapid determination of free proline for water stress studies. Plant Soil 39:205-207. https://doi.org/10.1007/BF00018060

26. Devi K, Haripriya S (2012) Pasting behaviors of starch and protein in soy flour-enriched composite flours on quality of biscuits. J Food Process Pres 38:116-124. https://doi.org/10.1 111/j.1745-4549.2012.00752.x

27. Singleton V, Rossi J (1965) Colorimetry of total phenolics with phosphomolybdic phosphotungstic acid reagents. Am J Enol Viticult 16:144-158. https://www.ajevonline.org/content/ ajev/16/3/144.full.pdf

28. Zhishen J, Mengcheng T, Jianming W (1999) The determination of flavonoid contents in mulberry and their scavenging effects on superoxide radicals. Food Chem 64:555-559. https ://doi.org/10.1016/S0308-8146(98)00102-2

29. Mukherjee S, Choudhuri MA (1983) Implications of water stress-induced changes in the levels of endogenous ascorbic acid and hydrogen peroxide in Vigna seedlings. Physiol Plant 58:166-170. https://doi.org/10.1111/j.1399-3054.1983.tb041 62.x

30. Broadhurst RB, Jones WT (2000) Analysis of condensed tannins using acidified vanillin. J Sci Food Agric 29:788-794. https://doi. org/10.1002/jsfa.2740290908

31. Tan SP, Vuong QV, Stathopoulos CE, Parks SE, Roach PD (2014) Optimized aqueous extraction of saponins from bitter melon for production of a saponin-enriched bitter melon powder. J Food Sci 79:E1372-E1381. https://doi.org/10.1111/1750-3841.12514

32. Blois MS (1958) Antioxidant determination by the use of stable free radical. Nature 181:1199-1200. https://www.nature.com/ articles/1811199a0.pdf

33. Re R, Pellegrini N, Proteggente A, Pannala A, Yang M, Rice-Evans $C$ (1999) Antioxidant activity applying an improved ABTS radical cation decolorization assay. Free Radic Biol Med 26:1231-1237. https://doi.org/10.1016/S0891-5849(98)00315-3

34. Garratt D (1964) The quantitative analysis of Drugs. Chapman and Hall Ltd., Boston

35. Wenli Y, Yaping Z, Bo S (2004) The radical scavenging activities of radix puerariae isoflavonoids: a chemiluminescence study. Food Chem 86:525-529. https://doi.org/10.1016/j.foodc hem.2003.09.005

36. Benzie IFF, Strain JJ (1996) The ferric reducing ability of plasma (FRAP) as measure of 'antioxidant power': the FRAP assay. Anal Biochem 76:70-76. https://doi.org/10.1006/abio.1996.0292
37. Indian Council of Medical Research (2017) National ethical guidelines for biomedical and health research involving human participants. Director-General, ICMR, New Delhi, India

38. Asadi SZ, Khan MA, Chamarthy RV (2020) Development and quality evaluation of cookies supplemented with concentrated fiber powder from chiku (Manilkara zapota L.). J Food Sci Technol. https://doi.org/10.1007/s13197-020-04695-w

39. Chauhan A, Saxena DC, Singh S (2016) Physical, textural, and sensory characteristics of wheat and amaranth flour blend cookies. Cogent Food Agric 2:1125773. https://doi. org/10.1080/23311932.2015.1125773

40. Díaz A, Bomben R, Dini C, Viña SZ, García MA, Ponzi M, Comelli $N$ (2019) Jerusalem artichoke tuber flour as a wheat flour substitute for biscuit elaboration. LWT 108:361-369. https://doi. org/10.1016/j.lwt.2019.03.082

41. Ho LH, Latif NWA (2016) Nutritional composition, physical properties, and sensory evaluation of cookies prepared from wheat flour and pitaya (Hylocereus undatus) peel flour blends. Cogent Food Agric 2:1136369. https://doi.org/10.1080/23311 932.2015.1136369

42. Kim GS, Park GS (2008) Quality characteristics of cookies prepared with lotus leaf powder. Korean J Food Cookery Sci 24:398-404

43. Pasqualone A, Bianco AM, Paradiso VM, Summo C, Gambacorta G, Caponio F (2014) Physico-chemical, sensory and volatile profiles of biscuits enriched with grape marc extract. Food Res Int 65:385-393. https://doi.org/10.1016/j.foodres.2014.07.014

44. Pasqualone A, Makhlouf FZ, Barkat M, Difonzo G, Summo C, Squeo G, Caponio F (2019) Effect of acorn flour on the physicochemical and sensory properties of biscuits. Heliyon 5:e02242. https://doi.org/10.1016/j.heliyon.2019.e02242

45. Awolu OO, Oluwaferanmi PM, Fafowora OI, Oseyemi GF (2015) Optimization of the extrusion process for the production of ready-to-eat snack from rice, cassava and kersting's groundnut composite flours. LWT 64:18-24. https://doi.org/10.1016/j. Iwt.2015.05.025

46. Teterycz D, Sobota A (2020) Legume flour as a natural colouring component in pasta production. J Food Sci Technol 57:301-309. https://doi.org/10.1007/s13197-019-04061-5

47. Shobha D, Kumar HVD, Sreeramasetty TA, Puttaramanaik GKTP, Shivakumar GB (2014) Storage influence on the functional, sensory and keeping quality of quality protein maize flour. J Food Sci Technol 51:3154-3162. https://doi.org/10.1007/s1319 7-012-0788-7

48. Akoja SS, Coker OJ (2018) Physicochemical, functional, pasting and sensory properties of wheat flour biscuit incorporated with Okra powder. Int J Food Sci Nutr 3:64-70

49. Bian Q, Sittipod S, Garg A, Ambrose RPK (2015) Bulk flow properties of hard and soft wheat flours. J Cereal Sci 63:88-94. https:// doi.org/10.1016/j.jcs.2015.03.010

50. Adebowale YA (2005) Variability in the physicochemical, nutritional and antinutritional attributes of six Mucuna species. Food Chem 89:37-48. https://doi.org/10.1016/j.foodc hem.2004.01.084

51. Adebowale AA, Sanni LO, Onitilo MO (2008) Chemical composition and pasting properties of tapioca grits from different cassava varieties and roasting methods. Afr J Food Sci 2:77-82

52. Awolu OO (2017) Optimization of the functional characteristics, pasting and rheological properties of pearl millet-based composite flour. Heliyon 3:e00240. https://doi.org/10.1016/j.heliy on.2017.e00240

53. Mohammed I, Ahmed AR, Senge B (2012) Effects of chickpea flour on wheat pasting properties and bread making quality. J Food Sci Tech 51:1902-1910. https://doi.org/10.1007/s1319 7-012-0733-9 
54. Öksüz T, Karakaş B (2016) Sensory and textural evaluation of gluten-free biscuits containing buckwheat flour. Cogent Food Agric 2:1178693. https://doi.org/10.1080/23311932.2016.11786 93

55. Adeyeye SAO (2020) Quality evaluation and acceptability of cookies produced from rice (Oryza glaberrima) and soybeans (Glycine max) flour blends. J Culin Sci Technol 18:54-66. https:// doi.org/10.1080/15428052.2018.1502113

56. Bala A, Gul K, Riar CS (2015) Functional and sensory properties of cookies prepared from wheat flour supplemented with cassava and water chestnut flours. Cogent Food Agric 1:1019815. https ://doi.org/10.1080/23311932.2015.1019815

57. Navaf M, Sunooj KV, Aaliya B, Sudheesh C, George J (2020) Physico chemical, functional, morphological, thermal properties and digestibility of Talipot palm (Corypha umbraculifera L.) flour and starch grown in Malabar region of South India. J Food Meas Charact 14:1601-1613. https://doi.org/10.1007/s1169 4-020-00408-1

58. Grasso S, Omoarukhe E, Wen X, Papoutsis K, Methven L (2019) The use of upcycled defatted sunflower seed flour as a functional ingredient in biscuits. Foods 8:305. https://doi. org/10.3390/foods8080305

59. Cheng YF, Bhat R (2016) Functional, physicochemical and sensory properties of novel cookies produced by utilizing underutilized jering (Pithecellobium jiringa Jack.) legume flour. Food Biosci 14:54-61. https://doi.org/10.1016/j.fbio.2016.03.002

60. Sibian MS, Riar CS (2020) Formulation and characterization of cookies prepared from the composite flour of germinated kidney bean, chickpea, and wheat. Legume Sci 2:e42. https://doi. org/10.1002/leg3.42

61. Asadi SZ, Khan MA (2020) The effect of beetroot (Beta vulgaris L.) leaves powder on nutritional, textural, sensorial and antioxidant properties of cookies. J Culin Sci Technol. https://doi.org/https ://doi.org/10.1080/15428052.2020.1787285

62. Mahloko LM, Silungwe H, Mashau ME, Kgatla TE (2019) Bioactive compounds, antioxidant activity and physical characteristics of wheat-prickly pear and banana biscuits. Heliyon 5:e02479. https ://doi.org/10.1016/j.heliyon.2019.e02479

63. Jan R, Saxena DC, Singh S (2016) Physico-chemical, textural, sensory and antioxidant characteristics of gluten - free cookies made from raw and germinated Chenopodium (Chenopodium album) flour. LWT 71:281-287. https://doi.org/10.1016/j. Iwt.2016.04.001

64. De Simas KN, Vieira LN, Podestá R, Müller CMO, Vieira MA, Beber RC, Reis MS, Barreto PLM, Amante ER, Amboni RDMC (2009) Effect of king palm (Archontophoenix alexandrae) flour incorporation on physicochemical and textural characteristics of gluten-free cookies. Int J food Sci Technol 44:531-538. https:// doi.org/10.1111/j.1365-2621.2008.01840.x

65. Alvarez-Jubete L, Wijngaard H, Arendt EK, Gallagher E (2010) Polyphenol composition and in vitro antioxidant activity of amaranth, quinoa buckwheat and wheat as affected by sprouting and baking. Food Chem 119:770-778. https://doi.org/10.1016/j. foodchem.2009.07.032

66. Morais $\mathrm{CP}$, Utpott $\mathrm{M}$, Flores $\mathrm{SH}$, Cesar Tondo $\mathrm{E}$, Thys, RCS, Barin JS, Costa AB da, Tischer B (2020) Nutritional, antioxidant and sensory evaluation of calcium-high content cookies prepared with purple sweet potato (Ipomoea Batatas L.) and kale (Brassica oleracea var. Acephala) Flours. J Culin Sci Technol. https://doi. org/10.1080/15428052.2020.1777919

67. Natukunda S, Muyonga JH, Mukisa IM (2016) Effect of tamarind (Tamarindus indica L.) seed on antioxidant activity, phytocompounds, physicochemical characteristics, and sensory acceptability of enriched cookies and mango juice. Food Sci Nutr 4:494-507. https://doi.org/10.1002/fsn3.311

68. Bhat NA, Wani IA, Hamdani AM (2020) Tomato powder and crude lycopene as a source of natural antioxidants in whole wheat flour cookies. Heliyon 6:e03042. https://doi.org/10.1016/j.heliy on.2019.e03042

69. Ambrose DCP, Lekshman R (2016) Quality attributes of cookies from banana centre core flour incorporated in wheat and refined flour. Food Sci Res J 7:141-147. https://doi.org/10.15740 /HAS/FSRJ/7.2/141-147

Publisher's Note Springer Nature remains neutral with regard to jurisdictional claims in published maps and institutional affiliations. 